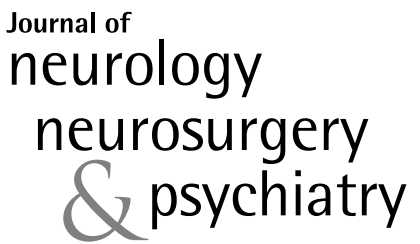

\title{
Ischaemic damage of brain microvessels: inherent risks for thrombolytic treatment in stroke
}

Recent trials of plasminogen activators in acute ischaemic stroke underscore the delicate balance between promise of benefit and risk. Attempts to manage clinical outcome by systemic infusion of recombinant tissue plasminogen activator (rt-PA) have so far had mixed success. ${ }^{12}$ The benefits seen in the National Institutes of Neurological Diseases and Stroke (NINDS) trial of rt-PA in acute ischaemic stroke were a significant absolute improvement in disability outcome. ${ }^{2}{ }^{3}$ However, the risks in that study and in the European Cooperative Acute Stroke Study (ECASS) ${ }^{1}$ included further disability and mortality associated with haemorrhagic consequences of the plasminogen activator (PA). ${ }^{12}$ Three recent studies of streptokinase in acute ischaemic stroke were terminated because of safety concerns. ${ }^{4-9}$ In all five trials, the risk of symptomatic haemorrhage associated with the PA was significantly increased over placebo (table 1). In addition, approaches which effect recanalisation of documented cerebral arterial thrombotic occlusions by intravenous or intra-arterial PA infusion have yet to be rigorously shown to promote overall benefit, although anecdotal evidence suggests that individual patients may improve clinically. ${ }^{10-24}$ The reasons are practical. The perceived risks, those of angiography and the interventional procedures required for intra-arterial PA delivery, have not been fully evaluated, ${ }^{25}$ although the relative risks of diagnostic angiography are low. ${ }^{26-28}$ Clearly, this assessment hides many important differences in PA behaviour, study design and conduct, patient populations, diagnostic and therapeutic procedures, disease severity, comorbidity, and a host of other potential contributors. None the less, concerns which may erode the promise of benefit of thrombolytic agents in acute ischaemic stroke include the accentuation of innate risks associated with the evolution of ischaemic injury after the stroke event itself. ${ }^{29-34}$ These include early mortality caused by severe brain oedema and the development of haemorrhagic transformation which causes clinical deterioration or death.

The nature of these risks and their augmentation by PAs are so far not completely understood. For rt-PAs they seem to encompass the time from onset of ischaemic stroke symptoms to treatment for documented middle cerebral artery (MCA) occlusion, ${ }^{35}$ diastolic hypertension, ${ }^{36}$ body mass, ${ }^{36}$ age ${ }^{37}$ signs of ischaemic injury at baseline, ${ }^{1}$ and perhaps other yet to be identified factors. It is clear that a reduction in the frequency of symptomatic intracerebral haemorrhage may substantially improve clinical outcome by reducing one significant contributor to mortality in each of the recent trials. ${ }^{124-929-3238}$ The thesis we consider here is that ischaemic injury to the microvasculature, manifest indirectly by early signs of focal ischaemic injury on CT, is central to the risks of oedema and of parenchymal haemorrhage. Here, we posit that appropriate patients with ischaemic stroke will derive further benefit from PAs if the territory and volume of damaged cerebral microvasculature, and thus the risk of oedema formation and symptomatic haemorrhage, is relatively small.

\section{The microvasculature as a target of ischaemic injury}

When blood flow through a feeding cerebral artery ceases, the downstream microvasculature is a proximate target. Although non-vascular cells have long been thought to be the primary target of ischaemic insults, events occurring at the blood-vascular-parenchymal interfaces are necessary for the initiation of tissue injury (figure A-D). During experimental focal cerebral ischaemia, with the fall in tissue oxygenation (1) microvascular permeability barriers are lost (figure $\mathrm{B})^{39-42}$; (2) the microvascular endothelium responds by the sequential expression of leucocyte adhesion receptors (figure $\mathrm{C})^{43-45}$; (3) the basal lamina and

Table 1 Odds ratio (OR) analysis of haemorrhagic transformation in trials of thrombolytic agents in acute ischaemic stroke

\begin{tabular}{|c|c|c|c|c|c|c|c|c|c|c|c|c|}
\hline \multirow[b]{2}{*}{ Trial } & \multicolumn{4}{|c|}{ All types of haemorrhages } & \multicolumn{4}{|c|}{ Symptomatic haemorrhages } & \multicolumn{4}{|c|}{ Fatal haemorrhages } \\
\hline & $\begin{array}{l}\text { Agent } \\
\text { odds }\end{array}$ & $\begin{array}{l}\text { Placebo } \\
\text { odds }\end{array}$ & $\begin{array}{l}\text { OR } \\
\text { (agent/ } \\
\text { placebo) }\end{array}$ & $95 \% C I$ & $\begin{array}{l}\text { Agent } \\
\text { odds }\end{array}$ & $\begin{array}{l}\text { Placebo } \\
\text { odds }\end{array}$ & $\begin{array}{l}\text { OR } \\
\text { (agent/ } \\
\text { placebo) }\end{array}$ & $95 \% C I$ & $\begin{array}{l}\text { Agent } \\
\text { odds }\end{array}$ & $\begin{array}{l}\text { Placebo } \\
\text { odds }\end{array}$ & $\begin{array}{l}\text { OR } \\
\text { (agent/ } \\
\text { placebo) }\end{array}$ & $95 \% C I$ \\
\hline ECASS & $134 / 179$ & $113 / 194$ & 1.3 & $0.93-1.77$ & $35 / 278$ & $9 / 298$ & 4.2 & $1.97-8.83$ & $19 / 294$ & $7 / 300$ & 2.8 & $1.15-6.69$ \\
\hline $\begin{array}{l}\text { NINDS } \\
\text { I+II }\end{array}$ & $34 / 278$ & $11 / 301$ & 3.3 & $1.66-6.73$ & $20 / 292$ & $2 / 310$ & 10.6 & $2.46-45.82$ & $9 / 303$ & $1 / 311$ & 9.2 & $1.16-73.36$ \\
\hline MAST-E & $49 / 88$ & $17 / 116$ & 3.8 & $2.04-7.04$ & $24 / 113$ & $4 / 129$ & 6.8 & $2.31-20.34$ & - & - & - & - \\
\hline MAST-I & $39 / 118$ & $16 / 140$ & 2.9 & $1.54-5.44$ & $10 / 147$ & $1 / 155$ & 10.5 & $1.33-83.40$ & - & - & - & - \\
\hline ASK & $56 / 118$ & $28 / 138$ & 2.3 & $1.40-3.92$ & $23 / 151$ & $5 / 161$ & 4.9 & $1.82-13.23$ & $17 / 157$ & $3 / 163$ & 5.9 & $1.69-20.47$ \\
\hline
\end{tabular}

The response to rt-PA or streptokinase treatment is shown by the OR for different trials. The OR is measured by dividing the odds for a certain outcome event of the rt-PA group (numerator) by the odds for this event of the placebo group (denominator). An OR of 1 means that the thrombolytic agent did not affect the incidence of haemorrhages. If the $95 \%$ CI does not cover unity, the incidence of haemorrhages is significantly enhanced or diminished by the treatment. $-=$ not available. In all trials a significant increase in all types of haemorrhages, of symptomatic haemorrhages, and of fatal haemorrhages was found. The NINDS trial showed the highest relative risk for fatal haemorrhages. 


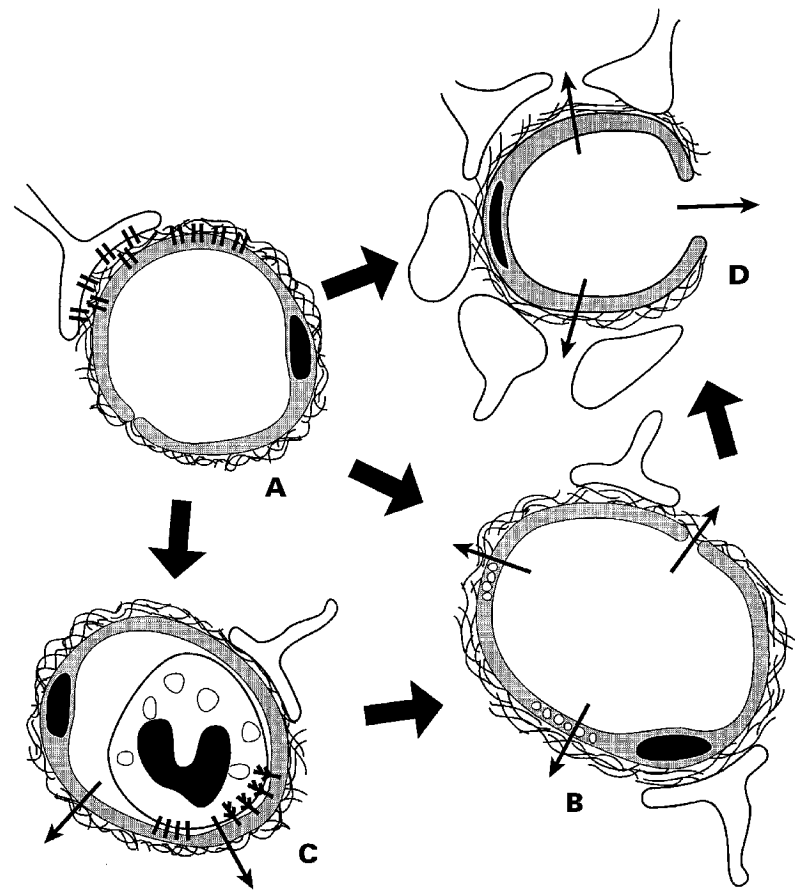

Schematic diagram of the effect of ischaemia on microvascular permeability and integrity. (A) Normal cerebral microvessel. Endothelial cells and astrocytes bound to basal lamina by integrin adhesion receptors. Blood-brain barrier intact. (B) Breakdown of blood-brain barrier. (C) Leucocyte adhesion by receptors on endothelium and granulocytes; increased permeability caused by granule release. (D) Breakdown of basal lamina with loss of astrocyte and endothelial cell contacts; permeability to large cells-for example, erythrocytes (see text).

extracellular matrix (ECM) undergo progressive loss of component antigens (figure D) ${ }^{46}$; and (4) cell-matrix adhesion interactions within microvessels are altered (figure D). ${ }^{47} 48$

\section{Microvascular permeability barriers}

The permeability barrier consists of: (1) the blood-brain barrier, represented by the interendothelial cell tight junctions which regulate substrate transfer ${ }^{39}{ }^{40} ;(2)$ the basal lamina, a structural barrier to the extravasation of cellular blood elements ${ }^{40}$; and (3) perivascular astrocytes which make up the parenchymal component of the microvasculature (figure A). ${ }^{51}$ With the loss of the endothelial cell permeability barrier, ${ }^{39}{ }^{40}$ and degradation of basal lamina/ ECM components, the brain parenchyma is exposed to the blood plasma and its cellular elements. ${ }^{39} 404651-53$

The formation of the endothelial blood-brain barrier relies on the interdependence of endothelial cells and astrocytes, as elegantly shown in chick-quail adrenal vascular tissue/brain tissue xenograft and fetal-adult hippocampal/neocortex allograft preparations. ${ }^{545}$ Astrocytes promote microvascular endothelial blood-brain barrier properties including tight junctions, dye exclusion, and antigenic features. ${ }^{40567}$ Coculture experiments have shown that soluble factors are necessary to maintain some of those barrier characteristics. ${ }^{55} 58$

Intact basal lamina also requires juxtaposition of the microvascular endothelium and astrocytes. ${ }^{60}{ }^{61}$ In culture, astrocytes can secrete the basal lamina/ECM components laminin and fibronectin, ${ }^{62}$ as well as chondroitin sulphate proteoglycan. ${ }^{63}$ Conversely, collagens stimulate astrocyte induced endothelial cell maturation. ${ }^{64}$ Microvascular endothelial cell derived ECM components stimulate astrocyte growth and generation of glutamine synthetase. ${ }^{656}$

The integrity of mature cerebral microvessels also seems to involve adhesion receptors which link the cellular components to specific ligands within the basal lamina/ECM.
For instance, it has recently been shown that integrin $\alpha_{1} \beta_{1}$, a receptor for the ECM ligands laminin-1 and collagen IV, is found on microvascular endothelium, ${ }^{47}$ and integrin $\alpha_{6} \beta_{4}$ is expressed on astrocyte end feet juxtaposed to its matrix ligand laminin $-5 .^{48}$ Hence, development of the blood-brain barrier and the basal lamina depend on the proximity of astrocytes to the endothelium, whereas the integrity of this relation involves cell matrix adhesion molecules.

\section{Focal ischaemia and changes in microvascular integrity}

After experimental MCA occlusion, microvascular expression of integrins $\alpha_{1} \beta_{1}$ and $\alpha_{6} \beta_{4}$ decreases rapidly in the region of focal ischaemia. ${ }^{47} \mathrm{~A}$ more gradual loss of laminin-1, laminin-5, cellular fibronectin, and collagen IV antigens within the basal lamina/ECM also occurs. ${ }^{46} 48$ Hamann et al demonstrated a significant correlation between the development of haemorrhagic transformation and the regional loss of basal lamina architecture by 24 hours after MCA occlusion. ${ }^{46} 5267$ Hence, haemorrhagic transformation occurs in regions where ischaemia causes a breakdown in the basal lamina, and disruption of adhesion between microvascular cellular components and the internal matrix scaffolding.

\section{Degradation of microvascular barriers}

The loss of constituents of the basal lamina and the rapid disappearance of related integrins may reflect down regulation of mRNA or protein synthesis, or degradation of mRNAs or proteins by enzymes secreted by endothelial cells, astrocytes, or circulating cells (figure D). At least three pathways may potentially lead to degradation of components of the basal lamina: (1) activation of plasminogen by endogenous PAs; (2) secretion of metalloproteinases (MMPs); and (3) release of PMN leucocyte specific granule enzymes. Non-ischaemic cerebral tissue generates PA activities. ${ }^{68}$ More specifically, cerebral microvascular endothelial cells express t-PA in situ ${ }^{69}$ and in vitro, ${ }^{71}$ whereas astrocytes produce t-PA and u-PA in response to specific mitogens. ${ }^{72}$ Matrix laminins are substrates for plasmin, ${ }^{73}{ }^{74}$ and plasmin activates MMP-1 (collagenase) and MMP-3. ${ }^{75}$ Certain MMPs released from vascular endothelium and leucocytes during the inflammatory phase of cerebral ischaemia employ collagen IV (MMP-1, MMP-2, and MMP-9) and laminin (MMP-2 and MMP-9) as substrates to promote tissue remodelling. ${ }^{76}{ }^{77}$ Gelatinases A (MMP-2) and B (MMP-9), which cleave collagen IV, are present in plasma. $^{78}$ Rosenberg et al have suggested that MMP- 9 appears by 24 hours after MCA occlusion in the anaesthetised rat. ${ }^{79} 80$ Also, enzymes from PMN leucocyte granules, including collagenase (MMP-8), elastase, and cathepsin G, released during their activation, degrade laminins and collagens. ${ }^{81-85}$ It is postulated that these pathways, unopposed by their inhibitors, may contribute to the dissolution of the basal lamina/ECM and the blood-brain barrier, thereby disrupting the normal relations of endothelium to astrocytes. ${ }^{8687}$

\section{Leucocytes and microvessel permeability}

Circulating leucocytes may promote changes in microvascular permeability at several levels. Adhesion of PMN leucocytes to specific endothelial cell receptors contributes to loss of microvascular patency, ${ }^{88-91}$ initiates diapedesis and transit into the parenchyma, and thereby adds to tissue injury (figure C). ${ }^{92}$ After MCA occlusion, P-selectin, ICAM-1, and E-selectin are expressed on cerebral microvascular endothelium in a distinct sequence. ${ }^{43}{ }^{44} \mathrm{P}$-selectin responds to thrombin generated during coagulation activation, histamine, activated complement, and superoxides. ${ }^{93-95}$ Astrocytes and microglia generate cytokines 
which stimulate endothelial cell-leucocyte adhesion receptor expression and promote chemotaxis. ${ }^{96-98}$ For instance, ICAM-1 and E-selectin appear in response to interleukin (IL) $-1 \beta$ and tumour necrosis factor (TNF) $-\alpha .^{99} 100$ These events initiate and expand the cellular inflammatory response to ischaemic injury. In addition, IL-1 has been shown to directly mediate neuron injury. ${ }^{96}{ }^{97}$ Blockade of IL-1 by exogenous IL-1 ra in a rodent MCA occlusion model has been associated with a significant reduction in ischaemic injury at 24 hours. ${ }^{97}$ During leucocyte transmigration and activation, the respiratory burst generates superoxide free radicals and release of granule proteolytic substances which contribute to blood-brain barrier, basal lamina/ECM, and perivascular tissue degradation. ${ }^{101}$ Cleavage products of laminins, generated by this process and by plasmins, are potent chemoattractants for leucocytes. ${ }^{102}$ The presence of complement C5 receptors on astroglial cells ${ }^{103}$ suggests the possibility that activated complement generated during ischaemic injury may also contribute to leucocyte activation. Free radicals, localised to ischaemic scattered cerebral microvascular endothelial and smooth muscle cells in vivo, ${ }^{104-106}$ may increase cerebral endothelial permeability and alter adhesion receptor distribution. ${ }^{107}$ In other systems, tissue haemorrhage accompanies tissue injury with inflammation. ${ }^{108}$

\section{Barrier loss and haemorrhagic transformation}

Extravasation of plasma and blood cells is initiated very early and becomes evident by 24 hours after experimental MCA occlusion in the corpus striatum..$^{52} 67109$ Haemorrhagic transformation seems tied to processes which alter the integrity of the blood-brain barrier and the basal lamina. In clinical preparations and certain experimental models, parenchymal haemorrhage has also been attributed to the impact of systemic blood pressure, the downstream movement of thromboemboli, or rupture of larger injured vessels which may have undergone degenerative changes. ${ }^{30} 110-113$ The distinguishing features are the rapid extravasation of blood leading to the compression of contiguous and adjacent tissues with loss of neurological function. ${ }^{30}{ }^{110}$ It is, so far, conjectural whether the processes leading to the development of coagula in the ischaemic zone begin with the microvascular events that lead to haemorrhagic infarction, ${ }^{33} 34$ however, vascular disintegration would seem to be necessary.

Several well known conditions which are aggravated by advancing age, long term hypertension, and diabetes target the microvasculature and may contribute to loss of microvascular integrity. ${ }^{114}$ These include lipohyalinosis or microangiopathy, which has been classified in three states of damage severity: ${ }^{115}$ (1) sclerotic and hyalinotic thickening of the vessel wall with onion skinning, which primarily affect arterioles $100-200 \mu \mathrm{m}$ diameter ${ }^{116}$; (2) additional disorganisation of the vessel wall and disruption of the internal elastic lamina with occasional foam cells (these changes may be associated with haematoma formation ${ }^{117}$; and (3) additional fibrinoid degeneration of the vessel wall with thrombosis. ${ }^{118}$ Importantly, deposition of amyloid in the vessel wall (amyloid angiopathy) leads to loss of vascular wall integrity, leakage, and later haemorrhagic changes. ${ }^{119-123}$ Most experimental models of focal ischaemia do not mimic these age-dependent vascular disturbances, which may also explain the rare occurrence of large haemorrhages in animal models compared with humans. Hence, loss of microvascular integrity may connect the experimental findings of blood cell extravasation to clinically important haemorrhagic transformation. ${ }^{35}$

\section{Oedema formation}

During focal cerebral ischaemia, increased microvascular permeability also leads to the entrance of fluid and plasma proteins into the injured region (figure B). ${ }^{124}$ In selected models, exposure of coagulation factors to perivascular tissue factor (TF) results in intravascular and extravascular fibrin deposition. ${ }^{125}{ }^{126}$ Here, thrombin is generated which may increase endothelial cell permeability. ${ }^{127-129}$ Platelet activating factor (PAF), TNF- $\alpha$, and bradykinin released during focal ischaemia also increase endothelial permeability. ${ }^{130-132}$ Furthermore, tissue haemorrhage itself may promote changes in permeability of the blood-brain barrier and oedema formation. ${ }^{133}$

Brain oedema develops immediately when regional cerebral blood (rCBF) falls below the threshold of structural integrity at $10-15 \mathrm{ml} / 100 \mathrm{~g} / \mathrm{min} .{ }^{124}{ }^{134-136}$ In a feline model, within 4 hours of MCA occlusion, cortical water content increased steadily from $80.7 \%$ to $83.0 \%$ wet weight. ${ }^{134}$ This $2.3 \%$ net uptake of water was accompanied by increased tissue $\mathrm{Na}^{+}$and decreased tissue $\mathrm{K}^{+}$concentrations, a shift of water from the extracellular into the intracellular compartment, and a linear increase in brain volume. ${ }^{134}$ Fluid entry involves osmotic and ionic gradients between blood and ischaemic brain tissue, and pinocytosis of water in the presence of residual plasma flow. ${ }^{137-140}$ Swelling within the ischaemic zone is explained by the failure of energy dependent membrane ion exchange pumps, subsequent influx of $\mathrm{Na}^{+}$and water into the intracellular compartment, resulting in cell hydrops at the expense of the size of the extracellular space. ${ }^{141}$ In the early stages of experimental focal ischaemic injury, increased transport of plasma markers is associated with increased pinocytosis in brain vascular endothelial cells consistent with attempts by the vasculature to compensate for decreased substrate delivery. ${ }^{142}{ }^{143}$ Here, the ultimate source of the expanded intracellular water compartment is vascular.

In focal ischaemia, the accumulation of tissue water may not resolve if reperfusion is achieved later than one hour after arterial occlusion. ${ }^{137}$ Moreover, reperfusion can further enhance oedema in areas of dense ischaemia. ${ }^{137}$ Subsequent studies in focal cerebral ischaemia indicate that PMN leucocytes may contribute further to tissue water accumulation in the injured territory. ${ }^{144-146}$ Taken from studies of oedema in the skin, ${ }^{147}$ it is possible that alterations of adhesive processes that bind neurons to their glial neighbours may further promote oedema formation.

\section{Oedema formation and early radiological signs of ischaemia}

The net uptake of water by the ischaemic brain tissue affects $x$ ray attenuation. ${ }^{148}{ }^{149}$ A $1 \%$ increase in content of tissue water causes a decrease of $x$ ray attenuation by 2 to 3 Hounsfield units (HU). ${ }^{150}$ After experimental MCA occlusion, tissue water uptake is detectable by CT which shows a linear decline in $x$ ray attenuation by about $1.5 \mathrm{HU} / \mathrm{h} .{ }^{151}$ Because of the normal noise in each CT image, a change of about $5 \mathrm{HU}$ is necessary for an increase in tissue water to be visible.

Shrinkage of the extracellular space causes a decrease in proton diffusion which is best detected by diffusion weighted MRI.$^{150} 152$ The detection of ischaemic changes by diffusion weighted MRI is immediate. ${ }^{153}$ The hyperintense area on the MRI representing diminished proton diffusion may be reversible during the first 2 hours after arterial occlusion, but later may correspond to irreversible tissue damage. ${ }^{154}$ Therefore, the presence of visible subtle hypoattenuation on CT is consistent with a minimum $2 \%$ focal uptake of water and an arterial occlusion which occurred some time earlier. The degree of hypoattenuation 
may be confounded by an increase in local cerebral blood volume, a well known compensatory mechanism for low perfusion pressure. ${ }^{155}$

From clinical experience, cerebral tissue hypoattenuation is regularly visible within the first 6 hours after the onset of ischaemic symptoms. The loss of the permeability barriers and entry of intravascular fluid, together with nonvascular cell injury contribute to early signs of ischaemic injury notable by CT: a regional decrease in $x$ ray attenuation and evidence of structural changes, marked by mass effect. This hypoattenuation can at an early stage delineate a volume of parenchymal tissue that will subsequently become necrotic and, if exceeding $50 \%$ of the MCA territory, is associated with a mortality of $85 \%$. ${ }^{156} 157$ It seems likely, but remains unestablished, that even very subtle hypoattenuation on CT and areas with restricted diffusion detected by MRI indicate oedema and irreversible tissue damage caused by sustained focal hypoperfusion. Whether oedema formation and microvascular haemorrhage are two manifestations of the same microvascular injury processes is of central relevance.

\section{Vascular contributors to ischaemic damage}

The degree of ischaemic injury in a cerebral arterial territory also depends on the intrinsic vulnerability of the tissue within that region. The volume of ischaemic cerebral tissue may depend on (1) protection by the collateral circulation (regional vascular flow characteristics), and (2) the vulnerability of selected non-vascular cells (selective cellular vulnerability) to the vascular territory at risk.

Experimental studies and clinical experience suggest that the corpus striatum is more sensitive to ischaemic injury than the overlying cortex following proximal MCA occlusion. ${ }^{158-160}$ This differential sensitivity is partly explained by vascular anatomical conditions: The cortex is protected by a net of leptomeningeal arteries which communicate with the parenchymal arterioles and between cortical territories, whereas the circle of Willis offers a continuous shunt of the basal brain supplying arteries. ${ }^{161}$ Furthermore, the microvascular network of the cortex is distinctly different from that of the corpus striatum. Developmental features of the rat cortical microvasculature, described by Bär et al, indicate a roughly three dimensional hexagonal network extending from the pial vessels to the grey matter-white matter border. ${ }^{162} 163$ This arrangement provides regional collateral vascular circuitry to shunt blood locally. ${ }^{164}$ In the non-human primate and in humans, flow is directed from the MCA to the corpus striatum through lenticulostriatal arterial (LSA) perforators. Here, erythrocyte transit time is increased, ${ }^{165}$ so that the regional $\mathrm{CBF}$ is closer to the threshold for ischaemic injury. In human patients and primates, the corpus striatum is particularly subject to unrecoverable injury after obstruction of the proximal (M1) MCA. ${ }^{159}$ Occlusion of the proximal MCA causes an immediate drop in blood flow in the territories supplied by the LSA, whereas the superficial cortex may be salvaged by leptomeningeal collaterals. ${ }^{166}$ In non-human primates after proximal MCA occlusion, haemorrhagic transformation is most often seen in the corpus striatum, where ischaemic injury is greatest. ${ }^{109}$

Selective vulnerability of neurons and glial cells is readily evident during experimental global cerebral ischaemia. ${ }^{167-171}$ The Purkinje cells of the cerebellum, medium sized striatal neurons, and the CA1 pyramidal cells of the hippocampus are especially sensitive. ${ }^{172}$ Histological damage may be apparent after about 3 minutes of ischaemia for hippocampal neurons, but after about 30 minutes for striatal neurons. ${ }^{172}{ }^{173}$ Furthermore, significant species and model differences in neuron vulnerabilities are possible. ${ }^{174}{ }^{175}$ Despite these distinct cellular vulnerabilities, there is no evidence that during focal cerebral ischaemia they contribute to haemorrhage. Rather, this seems to be more dependent on the sensitivity of microvascular structures to ischaemia.

Haemorrhagic transformation in embolic stroke Clinically, haemorrhagic transformation is manifest either by haemorrhagic infarction or parenchymal haematoma, or both. $^{34176}$ Okada et $a l^{32}$ and others ${ }^{31}$ have shown that haemorrhagic infarction is more common than parenchymal haematoma in patients with carotid territory embolic stroke. Parenchymal haematomas seem to accompany acute carotid territory embolism more often in the setting of anticoagulant treatment. ${ }^{176-181}$ The longstanding concept that haemorrhagic transformation may result from arterial reperfusion is so far not supported by angiographic studies. ${ }^{11} 1235182$ Ogata et al have suggested that haemorrhage may also occur from collateral channels or other vascular sources. ${ }^{183}$ Based on these clinical relations, it may be postulated that arterial reperfusion is dangerous when the microvascular basal lamina and matrix are disrupted by processes initiated by acute closure of the feeding artery. Regions of haemorrhagic transformation are likely to be those in which the microvascular beds are most vulnerable. Processes which disrupt microvascular structure (for example, amyloid deposition) may increase this vulnerability.

\section{Plasminogen activators, ischaemic injury, and haemorrhagic transformation}

Plasminogen activation carries an inherent risk of haemorrhage by altering platelet plug framework, vascular permeability, and vascular basal lamina integrity at sites of injury. ${ }^{184-186}$ Exogenous PAs might accelerate dissolution of the blood-brain barrier, microvascular basal lamina/ECM, and platelet-fibrin plugs thereby increasing oedema formation and the risk of haemorrhage. This hypothesis is consistent with the finding that the frequency of haemorrhagic transformation in the setting of rt-PA exposure increases with the time of intervention from symptom onset in patients with MCA occlusion, ${ }^{35}$ in whom intrinsically basal lamina/ECM dissolution increases with time from MCA occlusion. ${ }^{46}$

Five recent placebo controlled studies of intravenous PA infusion in acute ischaemic stroke highlight patient and study features which relate to the accentuated risk of haemorrhagic transformation (table 1). Three separate projects examined the relative benefits of $1.5 \times 10^{6}$ IU streptokinase, the recommended dose for acute myocardial infarction. ${ }^{187}{ }^{188}$ Hommel and colleagues of the Multicenter Acute Stroke Trial-Europe (MAST-E) reported a significantly higher incidence of symptomatic intracranial haemorrhage in the streptokinase group compared with placebo among patients treated within 6 hours of the onset of an MCA territory stroke. ${ }^{5}$ The significantly higher short term (10 day) mortality in the placebo group (18.1\%), suggested that the increased risk of symptomatic parenchymal haemorrhage with streptokinase was due to the increased severity of strokes entered into that trial. The Australia Streptokinase (ASK) Trial, which randomised patients to intravenous placebo or streptokinase administered within 4 hours of acute ischaemic stroke, noted a significantly increased mortality among patients treated after 3 hours. ${ }^{4}{ }^{6}$ The time from symptom onset to treatment did not seem to be relevant to the excess frequency of symptomatic haemorrhage in the streptokinase group. A third study, the Multicentre Acute Stroke Trial-Italy (MAST-I), which compared intravenous streptokinase \pm aspirin and placebo within 6 hours of onset of symptoms, was terminated when interim analysis showed a significant 
Table 2 Outcomes in patients ( $(\%)$ ) with no or small hypoattenuation $v$ large hypoattenuation on initial CT

\begin{tabular}{|c|c|c|c|c|c|c|c|}
\hline \multirow[b]{3}{*}{ Outcome event } & \multirow{3}{*}{$\begin{array}{l}\text { Time } \\
\text { (days) }\end{array}$} & \multicolumn{6}{|c|}{ CT findings within $6 \mathrm{~h}$ of stroke } \\
\hline & & \multicolumn{3}{|c|}{ Hypoattenuation $\leqslant 33 \%$ MCA territory } & \multicolumn{3}{|c|}{ Hypoattenuation $>33 \%$ MCA territory } \\
\hline & & Placebo & $r t-P A$ & $O R(95) C I)$ & Placebo & $r t-P A$ & $O R(95) C I)$ \\
\hline $\mathrm{PH}$ & 1 & $14 / 278(5)^{\star}$ & $47 / 269(17)^{\star}$ & $3.99(2.14-7.44)$ & $0 / 21(0)^{\star}$ & $9 / 31(29)^{\star}$ & - \\
\hline Mortality & 7 & $20 / 279(7)$ & $25 / 272(9)$ & $1.31(0.71-2.42)$ & $6 / 21(29)$ & $9 / 31(29)$ & $1.02(0.30-3.48)$ \\
\hline Mortality & 90 & $41 / 279(15)$ & $51 / 272(19)$ & $1.34(0.85-1.34)$ & $6 / 21(29)$ & $15 / 31(48)$ & $2.34(0.72-7.63)$ \\
\hline Rankin $=0+1$ & 90 & $81 / 277(29)^{\star}$ & $108 / 265(41)^{\star}$ & $1.66(1.17-2.38)$ & $3 / 21(14)$ & $2 / 31(6)$ & $0.41(0.06-2.72)$ \\
\hline
\end{tabular}

$\star_{2} \mathrm{p}<0.01$, Fisher's exact test between pairs within same hypoattenuation class.

$\mathrm{PH}=$ parenchymal haematoma. These data from the ECASS show for patients with an ischaemic oedema $>33 \%$ of the MCA territory (as detected as hypoattenuation on the initial CT scan) an increase in PH, a significantly higher early and late mortality, and a significantly smaller proportion of patients with beneficial outcome in the rt-PA group. The 52 patients with large ischaemic lesions were identified by an independent CT scan evaluation. Small differences in the incidence of outcome events are due to missing values. $-=$ Not calcuable.

excess of 10 day case fatalities associated with streptokinase \pm aspirin, but most particularly when streptokinase was given with aspirin. ${ }^{78}$ The incidences of haemorrhagic transformation detectable by CT at 5 days and symptomatic cerebral haemorrhage during the hospital stay among patients treated with streptokinase \pm aspirin significantly exceeded those in patients who received placebo.

ECASS, which tested the efficacy of rt-PA (alteplase) in acute ischaemic stroke applied within 6 hours of onset of symptom, did not show overall benefit in terms of disability outcome at 90 days. ${ }^{1}$ In that study, symptomatic brain haemorrhage was not defined as a primary outcome event. Intracranial haemorrhage was assessed on days 1 and 7 after treatment and categorised as haemorrhagic infarction or parenchymal haematoma. ${ }^{176}$ Haemorrhagic infarction on day 1 did not affect mortality outcome, which was $12 \%$ in patients with haemorrhagic infarction and $15 \%$ in patients without haemorrhage. However, parenchymal haematoma on day 1 was associated with a $52 \%$ mortality (von Kummer et al, unpublished data). The severity of initial clinical deficit and the presence of ischaemic changes on CT were associated with risk of haemorrhagic infarction. Increasing age and treatment with rt-PA were related to the risk of parenchymal haematoma. ${ }^{37}$ In the rt-PA treated group, the risk of parenchymal haematoma increased with the extent of hypoattenuation on the initial CT. ${ }^{189}$ In ECASS, the risk of cerebral haemorrhage was not apparently associated with the time from symptom onset to initiation of treatment, although the stroke population was heterogeneous with respect to aetiology.

The NINDS sponsored placebo controlled evaluation of rt-PA (alteplase) in patients with ischaemic stroke within 3 hours of onset of symptoms showed an $11 \%$ to $13 \%$ absolute improvement in best outcome using a composite of neurological outcome (NIHSS), two disability indices, and the Glasgow outcome score. ${ }^{2}$ Within an apparent equivocal effect on mortality was a significant increase in symptomatic intracerebral haemorrhage from $0.6 \%$ in the placebo group to $6.4 \%$ in the rt-PA group. One interpretation of those data is that the improvement in clinical outcome would have been substantially increased had the frequency of symptomatic haemorrhagic transformation been attenuated. This interpretation also applies to the ECASS experience. ${ }^{1}$

The excessive frequency of early symptomatic intracerebral haemorrhage in each trial could be attributed to the use of a plasminogen activator, and in at least two trials also to the severity of injury. ${ }^{15}$ In one trial, the impact of the injury on apparent risk may have been accentuated by an "excessive" dose of the streptokinase, and exposure of the injured microvascular bed to increased plasmin levels. ${ }^{5}$ In a subgroup of patients with evidence of ischaemic injury on the initial CT scan entered into ECASS, exposure to rt-PA significantly increased the frequency of symptomatic parenchymal haematoma within 24 hours (table 2). That experience implies that symptomatic haemorrhage complicates those regions with extensive early injury. Furthermore, a retrospective analysis of the NINDS dataset indicated that patients with severe strokes, or oedema, or mass effect on baseline CT had a higher frequency of intracerebral haemorrhage. ${ }^{3}$ A similar finding has been made in a placebo controlled study of intra-arterial infusion single chain urokinase plasminogen activator. ${ }^{25}$ These experiences are consistent with the postulate that the risk of symptomatic haemorrhage is a product of the depth and duration of ischaemic injury.

If it is true that the volume of brain tissue with irreversible ischaemic damage of microvessels is a dominant contributor to postischaemic cerebral haemorrhage, CT and MRI may identify patients with a potential increased risk of haemorrhage and mortality by exposure to PAs. Ueda et al have suggested that a threshold of $\mathrm{rCBF}$ reduction may be defined which is significantly associated with symptomatic intracerebral haemorrhage after PA exposure in acute stroke. ${ }^{190}$ From ECASS, evidence of tissue injury exceeding $33 \%$ of the MCA territory was associated with increased early symptomatic haemorrhage and mortality. ${ }^{189}$ The difficulty that CT and MRI findings during the first 2 hours may not be reliable because the disturbance of diffusion can be reversible ${ }^{191}$ or the CT may not display a lesion although oedema formation is ongoing temper this impression. However, if CT shows hypoattenuation during the first 2 hours after onset of symptoms, a territory with severe ischaemia and oedema is identified. In ECASS, 60 of $152(39 \%)$ patients examined within the first two hours of symptom onset showed hypoattenuation on their CT (which exceeded $33 \%$ of the MCA territory in 14 patients $(9 \%)) .{ }^{189}$ All patients with hypoattenuation on the initial CT independent of time of presentation showed necrosis on the follow up CT by 7 days (von Kummer, unpublished data).

Despite the apparent salutory effects of rt-PA in patients with ischaemic stroke treated within 3 hours of onset of symptoms, ${ }^{12}$ studies selecting and treating patients with ischaemic stroke with PAs based only on clinical criteria have shown an excess of symptomatic haemorrhage. ${ }^{124-8}$ This impression is supported by a recent meta-analysis. ${ }^{192} 193$ Among smaller studies in which patients were selected on the basis of location of occlusion, with recanalisation as an outcome measure, the frequency of symptomatic haemorrhage did not differ significantly from those receiving placebo. ${ }^{194}{ }^{195}$ In either case, if the hypothesis is correct that PAs may augment the dissolution of the microvascular basal lamina/ECM and thereby exacerbate haemorrhage based on their common characteristic to generate plasmin, then cerebral haemorrhage is likely to be a consequence. But the generation of plasmin necessary for thrombus lysis is intrinsic to PA activity and the consequences of plasmin generation on microvascular integrity are so far unalterable. So, attempts to decrease the clinical 
risk of plasminogen activator associated haemorrhagic transformation are necessary to improve overall outcome for patients and clinical studies.

The physician is currently left with applying strict criteria to select those patients with acute ischaemic stroke with attributes which may lower their intrinsic risk of haemorrhagic transformation. Specific characteristics which distinguish patients at risk for haemorrhage who receive a PA have not been resolved by experimental work and this is an important issue to be studied. Consideration of the roles that ischaemic microvascular injury may have in the processes of oedema formation and haemorrhagic transformation may guide that selection.

\section{DEFINITION OF THE REGION OF ISCHAEMIC INJURY BY CT OR MRI}

To reduce the inherent risk of intracerebral haemorrhage due to the PA, patients should be examined by CT or MRI to rule out primary haemorrhage as a cause of symptoms and to determine the volume of tissue which has had ischaemic injury. This is possible 2 hours after ictus, and in some patients even earlier. The critical volume of damaged tissue has yet to be determined. So far, a volume exceeding $33 \%$ of the MCA territory is associated with no benefit from PA and an increased risk for symptomatic haemorrhage.

\section{DURATION OF INJURY}

The designated time of onset of symptoms may underestimate the duration of ischaemic injury in some patients. Several uncontrolled and controlled studies have suggested that a decreased risk of haemorrhage is associated with shortened durations of ischaemic injury. Therefore, very early acquisition of patients to CT and potential treatment is required. Besides the need to initiate treatment very early, functional imaging methods to define the individual risk or extent of patients with sustained low rCBF on irreversibly damaged ischaemic tissue bear evaluation.

POTENTIAL CONTRIBUTORS TO MICROVASCULAR INJURY The microvasculature is also a target for ischaemic and inflammatory injuries with the general consequences of increased permeability to plasma and circulating cells. Sustained exposure to raised blood pressure, diabetes mellitus, amyloid angiopathy, and comorbid inflammatory conditions (for example, vasculitis) are likely to augment the effects of ischaemia on the microvascular bed.

PLASMINOGEN ACTIVATORS AND THE MICROVASCULATURE

There is as yet no specific experimental data on the relative effects of various PAs on microvascular integrity. Whether certain PAs may promote additional injury is unknown. However, agents which initiate complement activation (for example, streptokinase) ${ }^{196} 197$ and affect endothelial cell integrity (for example, streptokinase and rt-PA), ${ }^{184} 198$ could augment ischaemic microvascular injury. This argues that specific dose adjustment studies and prudent choice of agents should be an integral part of the testing of PAs in this setting. Furthermore, events which augment basal lamina and ECM dissolution (for example, increased inflammation) are likely to increase the risk of microvascular haemorrhage.

These issues are appropriate for further well conceived experimental work, but must also rigorously apply to the approved use of plasminogen activators in acute ischaemic stroke.

\section{Conclusions}

(1) Present experimental data allow the hypothesis that loss of microvascular integrity is one prerequisite for the devel- opment of haemorrhagic complications in focal cerebral ischaemia, with or without reperfusion.

(2) Loss of microvascular integrity may be increased by plasminogen activators although this has not been rigorously or prospectively examined.

(3) Because there is no currently available strategy to reduce or prevent loss of microvascular integrity during focal cerebral ischaemia, and therefore the intracerebral haemorrhagic complications, very careful patient selection based on clinical examination, CT, and perhaps MRI, must remain the current strategy.

We thank Marcia Filbert for her expert help in preparing this manuscript. This is publication number 11107-MEM from The Scripps Research Institute, La Jolla, CA, USA. This work was supported in part by grant RO1 NS 26945 of the National Institutes of Neurological Diseases and Stroke.

GREGORY J DEL ZOPPO

Department of Molecular and Experimental Medicine, The Scripps

Research Institute, La folla, California USA

RÜDIGER VON KUMMER

Department of Neuroradiology, Technische Universität Dresden, Dresden, Germany

GERHARD F HAMANN

Department of Neurology, Klinikum Grosshadern, Maximilians

Universität München, München, Germany

Correspondence to: Dr Gregory J del Zoppo, Department of Molecular and Experimental Medicine, The Scripps Research Institute, 10550 North Torrey Pines Road SBR-17, La Jolla, CA, USA. Telephone 001619784 9569; fax 001619784 8342; email grgdlzop@riscsm.scripps.edu

1 Hacke W, Kaste M, Fieschi C, et al. Intravenous thrombolysis with recombinant tissue plasminogen activator for acute hemispheric stroke. The European cooperative acute stroke study (ECASS). $\mathcal{J} A M A$
(n) European cooperat

2 The National Institutes of Neurological Disorders and Stroke rt-PA Stroke Study Group. Tissue plasminogen activator for acute ischemic stroke. $N$ Engl f Med 1995;333:1581-7.

3 The NINDS t-PA Stroke Study Group. Intracerebral hemorrhage after intravenous t-PA therapy for ischemic stroke. Stroke 1997;28:2109-18.

4 Donnan GA, Davis SM, Chambers BR, et al. Trials of streptokinase in severe acute ischaemic stroke. Lancet 1995;345:578-9.

5 Hommel M, Boissel JP, Cornu C, et al. Termination of trial of streptokinase in severe acute ischemic stroke [letter]. Lancet 1995;345:578-9.

6 Donnan GA, Davis SM, Chambers BR, et al. Streptokinase for acute ischemic stroke with relationship to time of administration. $f A M A$ 1996;276:961-6.

7 Multicentre Acute Stroke Trial-Italy (MAST-I) Group. Randomised controlled trial of streptokinase, aspirin, and combination of both in treatment of acute ischaemic stroke. Lancet 1995;346:1509-14.

8 Tognoni G, Roncaglioni MC. Dissent: an alternative interpretation of MAST-I. Lancet 1995;346:1504-15.

9 The Multicenter Acute Stroke Trial-Europe Study Group. Thrombolytic therapy with streptokinase in acute ischemic stroke. $N$ Engl $\mathcal{f}$ Med 1996;335:145-50

10 del Zoppo GJ, Zeumer H, Harker LA. Thrombolytic therapy in acute stroke: possibilities and hazards. Stroke 1986;17:595-607.

11 del Zoppo GJ, Ferbert A, Otis S, et al. Local intra-arterial fibrinolytic therapy in acute carotid territory stroke: a pilot study. Stroke 1988;19:30713.

12 Mori E, Tabuchi M, Yoshida T, et al. Intracarotid urokinase with thromboembolic occlusion of the middle cerebral artery. Stroke 1988;19:802-12.

13 Hacke W, Zeumer H, Ferbert A, et al. Intra-arterial thrombolytic therapy improves outcome in patients with acute vertebrobasilar occlusive disease. Stroke 1988;19:1216-22.

14 Zeumer H, Ringelstein EB, Hassel M, et al. Lokale Fibrinolysetherapie bei subtotaler Stenose der A. Cerebri Media. Dtsch Med Wochenschr 1983;108: $1103-5$.

15 Theron J, Courtheoux P, Casaseo A, et al. Local intra-arterial fibrinolysis in the carotid territory. AfNR Am F Neuroradiol 1989;10:753-65.

16 Zeumer H. Survey of progress: vascular recanalizing techniques in interventional neuroradiology. 7 Neurol 1985;231:287-94.

17 Zeumer H, Freitag HJ, Grzyka U, et al. Local intra-arterial fibrinolysis in acute vertebrobasilar occlusion. Technical developments and recent results. Neuroradiology 1989;31:336-40.

18 Higashida RT, Halbach VV, Barnwell SL, et al. Thrombolytic therapy in acute stroke. Fournal of Endovascular Surgery 1994;1:4-15.

19 Zeumer H, Freitag H-J, Zanella F, et al. Local intra-arterial fibrinolytic therapy in patients with stroke: urokinase vs recombinant tissue plasminogen activator (rt-PA). Neuroradiology 1993;35:159-62.

20 Fieschi C, Cavelletti C, Toni D, et al. Thrombolysis acute ischemic stroke. Acta Neurochir Suppl 1996;66:76-80.

21 Huemer M, Niederwieser V, Ladurner G. Thrombolytic treatment for acute occlusion of the basilar artery. F Neurol Neurosurg Psychiatry 1995;58:2278.

22 Barr JD, Mathis JM, Wildenhain SL, et al. Acute stroke intervention with intraarterial urokinase infusion. $\mathcal{F}$ Vasc Interv Radiol 1994;5:705-13.

23 Wijdicks EFM, Nichols DA, Thielen KR, et al. Intra-arterial thrombolysis in acute basilar artery thromboembolism: the initial Mayo Clinic experience. Mayo Clin Proc 1997;72:1005-13.

24 Cross DT, Moran CJ, Akins PT, et al. Relationship between clot location and outcome after basilar artery thrombolysis. AfNR Am $\mathcal{f}$ Neuroradiol 1997; 18:1221-8 
25 del Zoppo GJ, Higashida RT, Furlan AJ, et al. PROACT: a phase II randomized trial of recombinant pro-urokinase by direct arterial delivery in acute middle cerebral artery stroke. Stroke 1998;29:4-11.

26 Mani RL, Eisenberg RL, McDonald EJ, et al. Complications of catheter cerebral arteriography: analysis of 5000 procedures. I. Criteria and incidence. AfR Am F Roentgenol 1978;131:861-5.

27 Mani RL, Eisenberg RL. Complications of catheter cerebral arteriography: analysis of 5000 procedures. II. Relation of complication rates to clinical and arteriographic diagnosis. AfR Am f Roentgenol 1978;131:867-9.

28 Mani RL, Eisenberg RL, McDonald EJ, et al. Complications of catheter cerebral arteriography: analysis of 5000 procedures. III. Assessment of arteries injected, contrast medium used, duration of procedure, and age of patient. AfR Am f Roentgenol 1978;131:871-4.

29 Fischer EG, Ames A. Studies on mechanisms of impairment of cerebral circulation following ischemia: effect of hemodilution and perfusion pressure. Stroke 1972;3:538-42.

30 Fisher CM, Adams RD. Observations on brain embolism with special reference to hemorrhage infarction. In: Furlan AJ, ed. The heart and stroke. Exploring mutual cerebrovascular and cardiovascular issues. New York: Springer-Verlag, 1987;17-36

31 Yamaguchi T, Minematsu K, Choki J, et al. Clinical and neuroradiological analysis of thrombotic and embolic cerebral infarction. Fpn Circ f 1984;48: $50-8$.

32 Okada Y, Yamaguchi T, Minematsu K, et al. Hemorrhagic transformation in cerebral embolism. Stroke 1989;20:598-603.

33 del Zoppo GJ, Okada Y, Hamann G, et al. Mechanisms of fibrinolysisassociated hemorrhagic transformation. In: Yamaguchi T, Mori E, Mineratsu K, et al, eds. Thrombolytic therapy in acute ischemic stroke III. Tokyo: atsu K, et al, eds. Thrombolytic th
Springer Verlag, 1995;254-66.

34 Pessin MS, Teal PA, Caplan LR. Hemorrhagic infarction: guilt by association. AfNR Am f Neuroradiol 1991;12:1123-6.

35 del Zoppo GJ, Poeck K, Pessin MS, et al. Recombinant tissue plasminogen activator in acute thrombotic and embolic stroke. Ann Neurol 1992;32:7886.

36 Levy DE, Brott TG, Haley EC Jr, et al. Factors related to intracranial hematoma formation in patients receiving tissue type plasminogen activator for acute ischemic stroke. Stroke 1994;25:291-7.

37 Larrue V, von Kummer R, del Zoppo GJ, et al. Hemorrhagic transformation in acute ischemic stroke: potential contributing factors in the European in acute ischemic stroke: potential contributing factors
cooperative acute stroke study. Stroke 1997;28:957-60.

38 Hornig CR, Dorndorf W, Agnoli AL. Hemorrhagic cerebral infarction: a prospective study. Stroke 1986;17:179-85.

39 Risau W, Wolburg H. Development of the blood-brain barrier. TINS 1990; 13:174-8

40 Risau W, Hallmann R, Albrecht U, et al. Brain astrocytes induce the expression of an early cell surface marker for blood-brain barrier specific endothelium. EMBO F 1986;5:3179-83.

41 Betz AL, Keep RF, Beer ME, et al. Blood-brain permeability and brain concentration of sodium, potassium, and chloride during focal ischemia. $f$ Cereb Blood Flow Metab 1994;14:29-37.

42 Dietrich WD, Busto R, Halley $M$, et al. The importance of brain temperature in alterations of the blood-brain barrier following cerebral temperature in alterations of the blood-brain barri
ischemia. F Neuropathol Exp Neurol 1990;49:486-97.

43 Okada Y, Copeland BR, Mori E, et al. P-selectin and intercellular adhesion molecule-1 expression after focal brain ischemia and reperfusion. Stroke 1994;25:202-11.

44 Haring H-P, Berg EL, Tsurushita N, et al. E-selectin appears in non-ischemic tissue during experimental focal cerebral ischemia. Stroke 1996;27:1386-92.

45 del Zoppo GJ, Garcia JH. PMN leukocyte adhesion in cerebrovascular ischemia. In: Granger DN, et al, Physiology and pathophysiology of leukocyte adhesion. Oxford: Oxford University Press, 1994;408-33.

46 Hamann GF, Okada Y, Fitridge R, et al. Microvascular basal lamina antigens disappear during cerebral ischemia and reperfusion. Stroke 1995;26:2120-

del Zoppo GJ, Haring H-P, Tagaya M, et al. Loss of $\alpha_{1} \beta_{1}$ integrin immunoreactivity on cerebral microvessels and astrocytes following focal cerebral reactivity on cerebral microvessels and astrocytes following

48 Wagner S, Tagaya M, Koziol JA, et al. Rapid disruption of an astrocyte interaction with the extracellular matrix mediated by $\alpha_{6} \beta_{4}$ during focal cerebral ischemia/reperfusion. Stroke 1997;28:858-65.

49 Ment LR, Stewart WB, Ardito TA, et al. Germinal matrix microvascular maturation correlates inversely with the risk period for neonatal intraventricular hemorrhage. Brain Res 1995;84:142-9.

50 Park BH, Lavi E, Stieber A, et al. Pathogenesis of cerebral infarction and hemorrhage induced by a murine leukemia virus. Lab Invest 1994;70:7885.

51 Peters A, Palay BL, Webster Hd. The fine structure of the nervous system. Neurons and their supporting cells, 3rd ed. New York: Oxford University Press, 1991;352-3.

52 Hamann GF, Okada Y, del Zoppo GJ. Hemorrhagic transformation and microvascular integrity during focal cerebral ischemia/reperfusion. $\mathcal{f}$ Cereb Blood Flow Metab 1996;16:1373-8.

53 del Zoppo GJ. Microvascular changes during cerebral ischaemia and reperfusion. Cerebrovasc Brain Metab Rev 1994;6:47-96.

54 Janzer RC, Raff MC. Astrocytes induce blood-brain barrier properties in endothelial cells [letter]. Nature 1987;325:353-5

55 Hurwitz AA, Berman JW, Rashbaum WK, et al. Human fetal astrocytes induce the expression of blood-brain barrier specific proteins by autologous endothelial cells. Brain Res 1993;625:238-43.

56 Schlosshauer B, Herzog KH. Neurothelin: an inducible cell surface glycoprotein of blood-brain barrier specific endothelial cells and distinct neurons. F Cell Biol 1990;110:1261-74.

57 Lobrinus JA, Juillerat-Jeanneret L, Darekar P, et al. Induction of the bloodbrain barrier specific HT7 and neurothelin epitopes in endothelial cells of the chick chorioallantoic vessels by a soluble factor derived from astrocytes. Dev Brain Res 1992;70:207-11.

58 Minakawa T, Bready J, Berliner J, et al. In vitro interaction of astrocytes and pericytes with capillary-like structures of brain microvessel endothelium. pericytes with capillary-like
Lab Invest 1991;65:32-40.

59 Estrada C, Bready JV, Berliner JA, et al. Astrocyte growth stimulation by a soluble factor produced by cerebral endothelial cells in vitro. $\mathcal{F}$ Neuropathol Exp Neurol 1990;49:539-49.
60 Bernstein JJ, Getz R, Jefferson M, et al. Astrocytes secrete basal lamina after hemisection of rat spinal cord. Brain Res 1985;327:135-41.

61 Brooks PC, Montgomery AM, Rosenfeld M, et al. Integrin $\alpha_{\mathrm{v}} \beta_{3}$ antagonists promote tumor regression by promoting apoptosis of angiogenic blood vessels. Cell 1994;79:1157-64.

62 Webersinke G, Bauer H, Amberger A, et al. Comparison of gene expression of extracellular matrix molecules in brain microvascular endothelial cells and astrocytes. Biochem Biophys Res Commun 1992;189:877-84.

63 Ard MD, Faissner A. Components of astrocytic extracellular matrix are regulated by contact with axons. Ann N Y Acad Sci 1991;633:566-9.

64 Tagami M, Yamagata K, Fujino H, et al. Morphological differentiation of endothelial cells co-cultured with astrocytes on type-I or type-IV collagen. Cell Tissue Res 1992;268:225-32.

65 Kozlova M, Kentroti S, Vernadakis A. Influence of culture substrata on the differentiation of advanced passage glial cells in cultures from aged mouse cerebral hemispheres. Int f Dev Neurosci 1993;11:513-9.

66 Nagano N, Aoyagi M, Hirakawa K. Extracellular matrix modulates the proliferation of rat astrocytes in serum-free culture. Glia 1993;8:71-6.

67 Meyer JS. Importance of ischemic damage to small vessels in experimental cerebral infarction. $\mathcal{F}$ Neuropathol Exp Neurol 1958;17:577-85.

68 Sappino A-P, Madani R, Huarte J, et al. Extracellular proteolysis in the adult murine brain. f Clin Invest 1993;92:679-85.

69 Levin EG, del Zoppo GJ. Localization of tissue plasminogen activator in the endothelium of a limited number of vessels. Am F Pathol 1994;144:855-61.

70 Levin EG, Loskutoff DJ. Cultured bovine endothelial cells produce both urokinase and tissue-type plasminogen activators. F Cell Biol 1982;94:6316

71 Zlokovic BV, Wang L, Sun N, et al. Expression of tissue plasminogen activator in cerebral capillaries: possible fibrinolytic function of the blood-brain barrier. Neurosurgery 1995;37:955-61.

72 Tranque P, Robbins R, Naftolin F, et al. Regulation of plasminogen activators and type-1 plasminogen activator inhibitor by cyclic AMP and phorbol ester in rat astrocytes. Glia 1992;6:163-71.

73 Liotta LA, Goldfarb RH, Brundage R, et al. Effect of plasminogen activator (urokinase), plasmin, and thrombin on glycoprotein and collagenous components of basement membrane. Cancer Res 1981;41:4629-36.

74 Liotta LA, Goldfarb RH, Terranova VP. Cleavage of laminin by thrombin and plasmin: alpha thrombin selectively cleaves the beta chain of laminin. Thromb Res 1981;21:663-73.

75 Krane SM. Clinical importance of metalloproteinases and their inhibitors. In: inhibition of matrix metalloproteinases: therapeutic potential. RA Greenwald, LM Golub, eds. Ann N Y Acad Sci 1994;732:1-10.

76 Ueda Y, Imai K, Tsuchiya H, et al. Matrix metalloproteinase 9 (gelatinase B) is expressed in multinucleated giant cells of human giant cell tumor of bone and is associated with vascular invasion. Am f Pathol 1996;148:611-22.

77 Morodomi T, Ogata Y, Sasaguri Y, et al. Purification and characterization of matrix metalloproteinase 9 from U937 monocytic leukaemia and HT1080 fibrosarcoma cells. Biochem f 1992;285:603-11.

78 Vortio T, Baumann M. Human gelatinase/type IV collagenase is a regular plasma component. FEBS Lett 1989;155:285-9.

79 Rosenberg GA, Navratil M, Barone F, et al. Proteolytic cascade enzymes increase in focal cerebral ischemia in rat. $\mathcal{F}$ Cereb Blood Flow Metab 1996;16:360-6.

80 Rosenberg GA, Navratil M. Metalloproteinase inhibition blocks edema in intracerebral hemorrhage in the rat. Neurology 1997;48:921-6.

81 Murphy G, Reynolds JJ, Bretz U, et al. Collagenase is a component of the specific granules of human neutrophil leukocytes. Biochem f 1987;162:195-

82 Watanabe H, Hattori S, Katsuda S, et al. Human neutrophil elastase: degradation of basement membrane components and immunolocalization in the tissue. F Biochem 1990;108:753-9.

83 Line SR, Sabbaga J, Veiga SS, et al. Identification and characterization of highly conserved antigenic determinants in the laminin molecule. Braz $\mathcal{F}$ Med Biol Res 1990;23:841-55.

84 Heck LW, Blackburn WD, Irwin MH, et al. Degradation of basement membrane laminin by human neutrophil elastase and cathepsin G. Am f Pathol 1990;136:1267-74.

85 Pike MC, Wicha MS, Yoon P, et al. Laminin promotes the oxidative burst in human neutrophils via increased chemoattractant receptor expression. $\mathcal{F}$ Immunol 1989;142:2004-11.

86 Brenner CA, Adler RR, Rappotec RA, et al. Genes for extracellular-matrixdegrading metalloproteinases and their inhibitor, TIMP, are expressed during early mammalian development. Genes Dev 1989;3:848-59.

87 Khokha R, Denhardt DT. Matrix metalloproteinases and tissue inhibitor of metalloproteinases: a review of their role in tumorigenesis and tissue invasion. Invasion Metastasis 1989;9:391-405.

88 del Zoppo GJ, Schmid-Schönbein GW, Mori E, et al. Polymorphonuclear leukocytes occlude capillaries following middle cerebral artery occlusion and reperfusion in baboons. Stroke 1991;22:1276-83.

89 Mori E, Chambers JD, Copeland BR, et al. Inhibition of polymorphonuclear leukocyte adherence suppresses non-reflow after focal cerebral ischemia. Stroke 1992;23:712-8.

90 Little JR, Kerr FWL, Sundt TM Jr. Microcirculatory obstruction in focal cerebral ischemia: an electron microscopic investigation in monkeys. Stroke 1976;7:25-30.

91 Dawson DA, Ruetzler CA, Carlos TM, et al. Polymorphonuclear leukocytes and microcirculatory perfusion in acute stroke in the SHR. Keio $\mathcal{F}$ Med 1996;45:248-52.

92 Hallenbeck JM. Significance of the inflammatory response in brain ischemia. Acta Neurochir Suppl 1996;66:27-31.

93 Wagner DD. Weibel-Palade body: the storage granule for von Willebrand factor and P-selectin. Thromb Haemost 1993;70:105-10.

94 McIntyre TM, Patel KD, Zimmerman GA, et al. Oxygen radical-mediated leukocyte adherence. In: Granger DN, et al, Physiology and pathophysiology of leukocyte adhesion. New York: Oxford University Press, 1995;261-77.

95 Patel KD, Zimmerman GA, Prescott SM, et al. Oxygen radicals induce human endothelial cells to express GMP-140 and bind neutrophils. $\mathcal{F}$ Cell Biol 1991;112:749-59.

96 Rothwell NJ. Functions and mechanism of interleukin- 1 in the brain. Trends Pharmacol Sci 1991;12:430-5.

97 Loddick SA, Rothwell NJ. Neuroprotective effects of human recombinant interleukin-1 receptor antagonist in focal cerebral ischaemia in the rat. $f$ Cereb Blood Flow Metab 1996;16:932-40. 
98 Moreno-Flores MT, Bovolenta P, Nieto-Sampedro M. Polymorphonuclear leukocytes in brain parenchyma after injury and their interaction with purified astrocytes in culture. Glia 1993;7:146-57.

99 McEver RP. Selectins: novel receptors that mediate leukocyte adhesion during inflammation. Thromb Haemost 1991;65:223-8.

100 Weller A, Isenmann S, Vestweber D. Cloning of the mouse endothelial selectins: expression of both $\mathrm{E}$-and P-selectin is induced by tumor necrosis factor. $\mathcal{F}$ Biol Chem 1992;267:15176-83.

101 Del Maschio A, Zanetti A, Corada M, et al. Polymorphonuclear leukocyte adhesion triggers the disorganization of endothelial cell-to-cell adherens junctions. F Cell Biol 1996;135:497-510.

102 Harvath L, Brownson NE, Fields GB, et al. Laminin peptides stimulate human neutrophil motility. F Immunol 1994;152:5447-56.

103 Gasque P, Chan P, Fontaine M, et al. Identification and characterization of the complement $\mathrm{C} 5 \mathrm{a}$ anaphylatoxin receptor on human astrocytes. $\mathcal{F}$ Immunol 1995;155:4882-9.

104 Kontos CD, Wei EP, Williams JI, et al. Cytochemical detection of superoxide in cerebral inflammation and ischemia in vivo. Am f Physiol 1992;263: H1234-42.

105 Chan PH. Role of oxidants in ischemic brain damage. Stroke 1996;27: 1124-9.

106 Nelson CW, Wei EP, Povlishock JT, et al. Oxygen radicals in cerebral ischemia. Am f Physiol 1992;263:H1356-62.

107 Bradley JR, Johnson DR, Pober JS. Endothelial activation by hydrogen peroxide. Selective increases of intercellular adhesion molecule-1 and major histocompatibility complex class I. Am f Pathol 1993;142:1598-609.

108 Claudio L, Martiney JA, Brosnan CF. Ultrastructural studies of the bloodretina barrier after exposure to interleukin- $1 \beta$ or tumor necrosis factor- $\alpha$. Lab Invest 1994;70:850-61.

109 del Zoppo GJ, Copeland BR, Anderchek K, et al. Hemorrhagic transformation following tissue plasminogen activator in experimental cerebral infarction. Stroke 1990;21:596-601.

110 Fisher CM, Adams RD. Observations on brain embolism with special reference to the mechanism of hemorrhagic infarction. $\mathcal{F}$ Neuropathol Exp Neurol 1951;10:92-4.

111 Globus JH, Epstein JA, Green MA, et al. Focal cerebral hemorrhage experimentally induced. F Neuropathol Exp Neurol 1949;8:653-70.

112 Hain RF, Westhaysen PU, Swank RL. Hemorrhagic cerebral infarction by arterial occlusion. F Neuropathol Exp Neurol 1952;11:34-43.

113 Globus JH, Epstein JA. Massive cerebral hemorrhage: spontaneous and experimentally induced. f Neuropathol Exp Neurol 1953;12:107-33.

114 Lammie GA, Brannan F, Slattery J, et al. Nonhypertensive cerebral smallvessel disease. An autopsy study. Stroke 1997;28:2222-9.

115 Besson G, Hommel M. Lacunar syndromes. Adv Neurol 1993;62:141-60.

16 Verny M, Seilnean D, Duyckaerts C, et al. Vieillissement vasculaire cerebral. Ann Cardiol Angeiol (Paris) 1991;40:301-8.

117 Poirier J, Derouesne C. Cerebral lacunae: a proposed new classification. Clin Neuropathol 1984;3:266.

118 Brun A, Fredriksson K, Gustafson L. Pure subcortical aterosclerotic encephalopathy (Binswanger disease): a clinicopathological study. Cerebrovasc Dis 1992;2:87-92.

119 Vinters HV, Wang ZZ, Secor DL. Brain parenchymal and microvascular amyloid in Alzheimer's disease. Brain Pathol 1996;6:179-95.

120 Vonsattel JP, Myers RH, Hedley-Whyte ET, et al. Cerebral amyloid angiopathy without and with cerebral hemorrhages: a comparative histological ptudy. A n Neurol 1991;30:637-49.

121 Melo TP, Bougousslavsky J, Regli F, et al. Fatal hemorrhage during anticoagulation of cardioembolic infarction: role of cerebral amyloid angiopathy. Eur Neurol 1993;33:9-12.

122 Greenberg SM, Rebeck GW, Vonsattel JP, et al. Apolipoprotein E epsilon 4 and cerebral hemorrhage associated with amyloid angiopathy. Ann Neurol 1995;38:254-9.

123 Nicoll JA, Burnett C, Love S, et al. High frequency of apolipoprotein E epsilon 2 allel in hemorrhage due to cerebral amyloid angiopathy. Ann Neurol 1997;41:716-21.

124 Symon L, Branston N, Chikovani O. Ischemic brain edema following middle cerebral artery occlusion in baboons: relationship between regional cer-
ebral water content and blood flow at 1 to 2 hours. Stroke 1979;10:184-91.

125 Okada Y, Copeland BK, Tung M-M, et al. Fibrin forms in the perivascular tissue during focal cerebral ischemia and reperfusion. Stroke 1994;25:266.

126 Thomas WS, Mori E, Copeland BR, et al. Tissue factor contributes to microvascular defects following cerebral ischemia. Stroke 1993;24:847-53.

127 Moy AB, Van Engelenhoven J, Bodmer J, et al. Histamine and thrombin modulate endothelial focal adhesion through centripetal and centrifugal orces. F Clin Invest 1996;97:1020-7.

128 Van Hinsbergh VWM. Endothelial permeability for macromolecules. Mechanistic aspects of pathophysiological modulation. Arteriosclerosis, Thrombosis, and Vascular Biology 1997;17:1018-23.

129 Garcia JGN, Pavalko FM, Patterson CE. Vascular endothelial cell activation and permeability responses to thrombin. Blood Coagul Fibrinolysis 1995;6:609-26.

130 Bhoola KD, Figueroa CD, Woerthy K. Bioregulation of kinins: kallikreins, kininogens, and kininases. Pharmacol Rev 1992;44:1-80.

131 Geppetti P. Sensory neuropeptide release by bradykinin: mechanisms and pathophysiological implications. Regul Pept 1993;47:1-23.

132 Relton JK, Beckey VE, Hanson WL, et al. CP-0597, a selective bradykinin $\beta_{2}$ receptor antagonist, inhibits brain injury in a rat model of reversible middle cerebral artery occlusion. Stroke 1997;28:1430-6.

133 Yang G-Y, Betz AL, Chenevert TL, et al. Experimental intracerebral hemorrhage: relationship between brain edema, blood flow, and bloodbrain barrier permeability in rats. $\mathcal{F}$ Neurosurg $1994 ; 81: 93-102$

134 Schuir FJ, Hossmann KA. Experimental brain infarcts in cats. II. Ischemic brain edema. Stroke 1980;11:593-601.

135 Symon L, Branston NM, Strong AJ, et al. The concept of thresholds of schaemia in relation to brain structure and function. F Clin Pathol 1977;30: 149-54.

136 Hossmann KA. Viability thresholds and the penumbra of focal ischemia. Ann Neurol 1994;36:557-65.

137 Ianotti F, Hoff J. Ischemic brain edema with and without reperfusion: an experimental study in gerbils. Stroke 1983;14:562-7.

138 Hossmann K, Takagi S. Osmolality of brain in cerebral ischemia. Exp Neurol 1976;51:124-31. 139 Siesjö B. Cerebral circulation and metabolism. F Neurosurg 1984;60:883-
140 Siesiö B. Pathophysiology and treatment of focal cerebral ischemia. $\mathcal{f} \mathrm{Neu}$ rosurg 1992;77:169-84.

141 Kimelberg HK. Current concepts of brain edema: review of laboratory investigators. F Neurosurg 1995;83:1051-9.

42 Petito C. Early and late mechanisms of increased vascular permeability following experimental cerebral infarction. F Neuropathol Exp Neurol 1979;38 $222-34$

143 Raichle M. The pathophysiology of brain ischemia. Ann Neurol 1983;13:210.

144 Matsuo Y, Onodera H, Shiga Y, et al. Role of cell adhesion molecules in brain injury after transient middle cerebral artery occlusion in the rat. Brain Res 1994;656:344-52.

145 Matsuo Y, Onodera H, Shiga Y, et al. Correlation between myeloperoxidase-quantified neutrophil accumulation and ischemic brain injury in the rat. Effects of neutrophil depletion. Stroke 1994;25:1469-75.

146 Matsuo Y, Kihara T, Ikeda M, et al. Role of neutrophils in radical production during ischemia and reperfusion of the rat brain: effect of neutrophil depletion on extracellular ascorbyl radical formation. 7 Cereb Blood Flow Metab 1995;15:941-7.

147 Reed RK, Rubin K, Wiig H, et al. Blockade of $\beta_{1}$-integrins in skin causes edema through lowering of interstitial fluid pressure. Circ Res 1992;71:978

148 Rieth KG, Fujiwara K, De Chiro G, et al. Serial measurements of CT attenuation and specific gravity in experimental cerebral edema. Radiology 1980;135:343-8

149 Torack RM, Alcala H, Gado M, et al. Correlative assay of computerized cranial tomography (CT), water content and specific gravity in normal and pathological postmortal brain. F Neuropathol Exp Neurol 1976;35:385-92.

150 Unger E, Littlefild J, Gado M. Water content and water structure in CT and MR signal changes: possible influence in detection of early stroke. AfNR Am f Neuroradiol 1988;9:687-91.

151 von Kummer R, Weber J. Brain and vascular imaging in acute ischemic stroke: the potential of computed tomography. Neurology 1997;49(suppl 4):S52-5

152 Moseley M, Cohen Y, Mintorovitch J, et al. Early detection of regional cerebral ishcemia in cats: comparison of diffusion- and T2-weighted MRI and spectroscopy. Magn Reson Imaging 1990;14:330-45.

153 Kohno K, Back T, Hoehn-Berlage M, et al. Relationship between diffusion-weighted magnetic resonance images, cerebral blood flow, and energy state in experimental brain infarction. Magn Reson Imaging

154 Back T, Hoehn-Berlage M, Kohno K, et al. Diffusion NMR imaging in experimental stroke: correlation with cerebral metabolites. Stroke 1994;25: $494-500$.

155 Wise R, Bernardi S, Frackowiak R, et al. Serial observation on the pathophysiology of acute stroke. The transition from ischaemia to infarction as reflected in regional oxygen extraction. Brain 1983;106:197-222.

156 von Kummer R, Meyding-Lamade U, Forsting M, et al. Sensitivity and prognostic value of early CT in occlusion of the middle cerebral artery trunk. AfNR Am f Neuroradiol 1994;15:9-15.

157 Truwit CL, Barkovich AJ, Gean-Marton A, et al. Loss of the insular ribbon: another early CT sign of acute middle cerebral artery infarction. Radiology 6:801-6.

158 Pulsinelli W, Brierley J, Plum F. Temporal profile of neuronal damage in a

59 Bozzao L, Fantozzi LM, Bastianello S, et al. Early collateral blood supply and late parenchymal brain damage in patients with middle cerebral artery occlusion. Stroke 1989;20:735-40.

60 Garcia JH, Liu K-F, Ho K-L. Neuronal necrosis after middle cerebral artery occlusion in Wistar rats progresses at different time intervals in the caudoputamen and the cortex. Stroke 1995;26:636-43.

161 Mishkin MM, Schreiber MN. Collateral circulation. In: Newton TH, et al, Radiology of the skull and brain. Vol. 2. St Louis: CV Mosby 1974;2344-74.

162 Bär T. Morphometric evaluation of capillaries in different laminae of rat cerebral cortex by automatic image analysis: charges during development and aging. In: Cervos-

163 Bär T, Wolff JR The formation of capillary basement membranes during internal vascularization of the rat's cerebral cortex. $Z$ Zellforsch 1972;133: 231-48.

164 Edvinsson L, MacKenzie ET, McCulloch J. General and comparative anatomy of the cerebral circulation. In: Cerebral blood flow and metabolism. New York: Raven Press, 1993;3-39.

165 Fenstermacher J, Nakata H, Tajima A, et al. Functional variations in parenchymal microvascular systems within the brain. Magn Reson Med 1991;19:217-20

166 Zülch K-J. The cerebral infarct:pathology, pathogenesis, and computed tomography. Heidelberg: Springer-Verlag, 1985;23-9.

167 Weiloch T. Neurochemical correlates to selective neuronal vulnerability. Prog Brain Res 1985;63:69-85.

168 Pulsinelli WA. Selective neuronal vulnerability: Morphological and molecular characteristics. Prog Brain Res 1985;63:29-37.

169 Schreiber SS, Baudry M. Selective neuronal vulnerability in the hippocampus - a role for gene expression? Trends Neurosci 1995;18:446-51.

170 Bergeron C, Petrunka C, Weyer L. Copper/zinc superoxide dismutase expression in the human central nervous system. Correlation with selective neuronal vulnerability. Am f Pathol 1996;148:273-9.

171 Garcia JH. Morphology of global cerebral ischemia: a review. Crit Care Med

172 Durkin JP, Tremblay R, Chakravarthy B, et al. Evidence that the early loss of membrane protein kinase $\mathrm{C}$ is a necessary step in the excitatory amino acid-induced death of primary cortical neurons. F Neurochem 1997;68: $1400-12$.

173 Kuroiwa T, Terakado M, Yamaguchi T, et al. The pyramidal cell layer of sector CA 1 shows the lowest hippocampal succinate dehydrogenase activity in normal and postischemic gerbils. Neurosci Lett 1996;206:117-20.

174 Tagaya M, Liu K-F, Copeland B, et al. DNA scission following focal brain ischemia: temporal differences in two species. Stroke 1997;28:1245-54.

175 Young AR, Touzani O, Derlon J-M, et al. Early reperfusion in the anesthetized baboon reduces brain damage following middle cerebral artery occlusion: a quantitative analysis of infarction volume. Stroke 1997;28:632-

176 Pessin M, del Zoppo G, Estol C. Thrombolytic agents in the treatment of stroke. Clin Neuropharmacol 1990;13:271-89. 
177 Drake ME, Shin C. Conversion of ischemic to hemorrhagic infarction by nticoagulant administration. Report of two cases with evidence from serial computed tomographic brain scans. Arch Neurol 1983;40:44-6.

178 Meyer JS, Gilroy J, Barnhart MI, et al. Therapeutic thrombolysis in cerebral thromboembolism. Neurology 1963;13:927-37.

179 Babikian VL, Kase CS, Pessin MS, et al. Intracerebral hemorrhage in stroke patients anticoagulated with heparin. Stroke 1989;29:1500-3.

180 Furlan AJ, Cavalier SJ, Hobbs RE, et al. Hemorrhage and anticoagulation after nonseptic embolic brain infarction. Neurology 1982;32:280-2.

181 Koller RL. Recurrent embolic cerebral infarction and anticoagulation. Neurology 1982;32:283-5.

182 Mori E, Yoneda Y, Ohkawa S, et al. Double-blind placebo-controlled trial of intravenous recombinant tissue plasminogen activator (rt-PA) in acute carotid stroke [abstract]. Neurology 1991;41(suppl 1):347.

183 Ogata J, Yutani C, Imakita M, et al. Hemorrhagic infarct of the brain without a reopening of the occluded arteries in cardioembolic stroke. Stroke 1989;20:876-83.

184 Rudd MA, Johnstone MT, Rabbani LE, et al. Thrombolytic therapy causes an increase in vascular permeability that is reversed by 1 -deamino-8-Dan increase in vascular permeability that is

185 Okajima K, Abe H, Binder BR. Endothelial cell injury induced by plasmin in vitro. F Lab Clin Med 1995;126:377-84.

186 Rabbani LE, Johnstone MT, Rudd MA, et al. PPACK attenuates plasmininduced changes in endothelial integrity. Thromb Res 1993;70:425-36.

187 Gruppo Italiano Per Lo Studio Della Streptochinasi Nell'Infarto Miocardico (GISSI). Effectiveness of intravenous thrombolytic treatment in acute myocardial infarction. Lancet 1986;i:397-401.

188 Gruppo Italiano Per Lo Studio Della Streptochinasi Nell'Infarto Miocardico (GISSI). GISSI-2: a factorial randomized trial of alteplase versus streptokinase and heparin versus no heparin among 12490 patients with acute myocardial infarction. Lancet 1990;336:65-71.
189 von Kummer R, Allen KL, Holle R, et al. Acute stroke: usefulness of early CT findings before thrombolytic therapy. Radiology 1997;205:327-33.

190 Ueda T, Hatakeyama T, Kumon Y, et al. Evaluation of risk of hemorrhagic transformation in local intra-arterial thrombolysis in acute ischemic stroke by initial SPECT. Stroke 1994;25:298-303.

191 Minematsu K, Li L, Sotak C, et al. Reversible focal ischemic injury demonstrated by diffusion-weighted resonance imaging in rats. Stroke 1992;23:1304-11.

192 Wardlaw JM, Yamaguchi T, del Zoppo GJ, et al. The efficacy and safety of thrombolytic therapy in acute ischaemic stroke: a systematic review of the randomised trials comparing thrombolysis with control. In: Warlow C, et al, Stroke module of the Cochrane database of systematic reviews. London: BMJ Stroke module of the Cochrane

193 Wardlaw JM, Warlow CP, Counsell C. Systemic review of evidence on thrombolytic therapy for acute ischaemic stroke. Lancet 1997;350:607-14.

194 Mori E, Yoneda Y, Tabuchi M, et al. Intravenous recombinant tissue plasminogen activator in acute carotid artery territory stroke. Neurology 1992; 42:976-82.

195 Yamaguchi T, Hayakawa T, Kikuchi H. Intravenous tissue plasminogen activator ameliorates the outcome of hyperacute embolic stroke. Cerebrovasc Dis 1993;3:269-72.

196 Lynch M, Pentecost BL, Littler WA, et al. Why do patients develop reactions to streptokinase? $\mathcal{F}$ Exp Immunol 1993;94:279-85.

197 Agostoni A, Gardinali M, Frangi D, et al. Activation of complement and kinin systems after thrombolytic therapy in patients with acute myocardial infarction. A comparison between streptokinase and recombinant tissuetype plasminogen activator. Circulation 1994;90:2666-70.

198 Montrucchio G, Lupia E, De Martino A, et al. Plasmin promotes an endothelium-dependent adhesion of neutrophils. Involvement of platelet activating factor and P-selectin. Circulation 1996;93:2152-60.

\section{NEUROLOGICAL STAMP}

\section{Ferdinand Jakob Heinrich von Müller (1825-96)}

Ferdinand Jakob Heinrich von Müller was born in Rostock, Germany. Müller was a qualified pharmacist who then studied medicine but abandoned this due to his health. In 1847 he emigrated to Australia where he collected plants for research. He wrote an 11 volume book Plants in Australia (1855-1881).

Many of Australia's native plants were sent overseas by Müller to chemists so that their curative properties might be investigated. He wrote and lectured on medical and poisonous plants, stressed the commercial importance of eucalyptus oil, and wrote extensively on Cinchona calisaya, from which quinine is prepared. $\mathrm{He}$ was appointed Director of the Melbourne Botanical Gardens and became a medical examiner for the University of Sydney. He received 184 civil and scientific honours during his life. For his contribution to biological science he was awarded the degree of Doctor of Medicine Honoris Causa in 1857 by the University of Rostock.

Philatelically Australia honoured him on a stamp issued in 1948. His portrait is shown with a sprig of the gum that bears his name, Eucalyptus muelleriana. (Stanley Gibbons 226, Scott 214).

L F HAAS

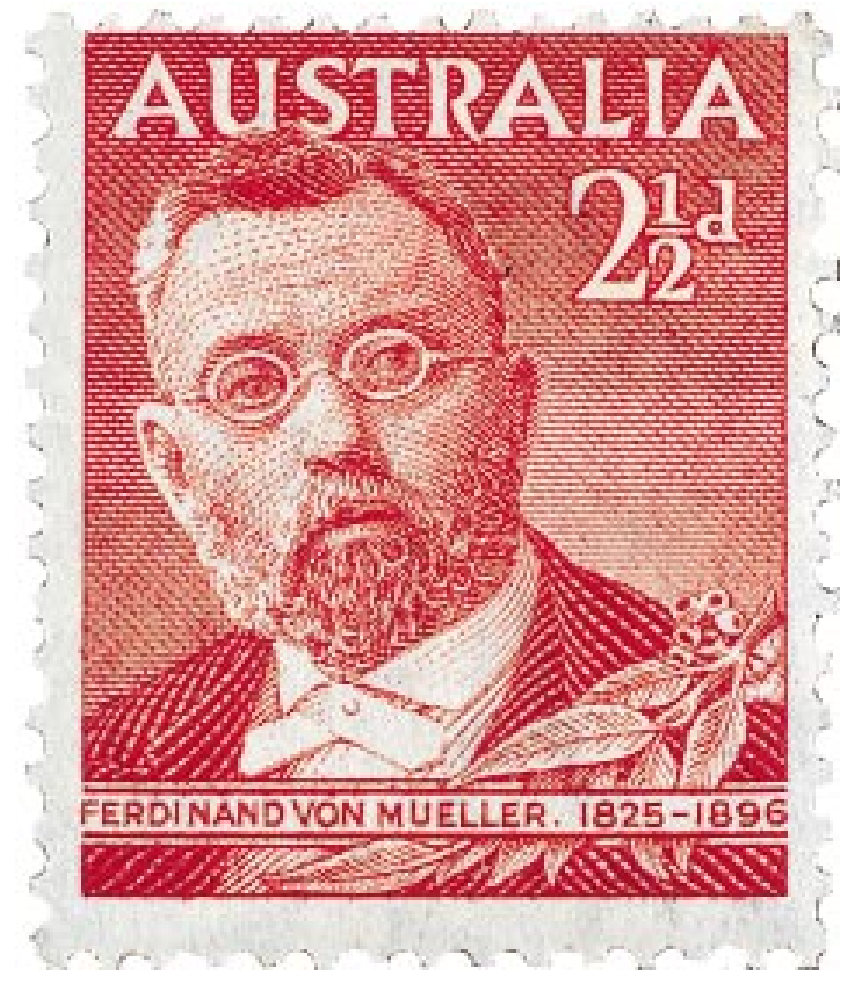

